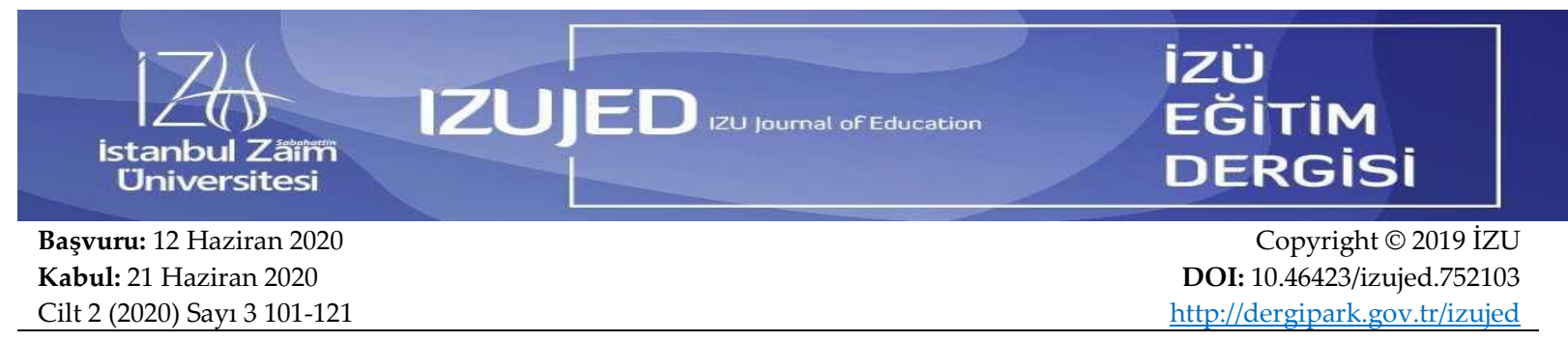

\title{
Gelişimsel Yetersizliğe Sahip Çocuğu Olan ve Normal Gelişim Gösteren Çocuğa Sahip Ebeveynlerin Aile Yaşam Kalitesi Algılarının İncelenmesi*
}

\author{
Hande KARADUMANa
}

Hanifi PARLAR ${ }^{b}$

\begin{abstract}
Öz
Araştırmanın amacı, normal gelişen çocuklu anne-babalar ile gelişimsel yetersizliğe sahip çocuklu annebabaların aile yaşam kalitelerini incelemektir. Veri setini, İstanbul ilinde yaşayan gelişimsel yetersizliğe sahip çocuklu 223 anne-baba ve çocuğu normal gelişen 68 anne-baba olmak üzere toplamda 291 annebaba doldurmuştur. Araştırmada veriler "Kişisel Bilgi Formu" ve ebeveynlerin yaşam kalitesini belirlemek amacı ile Hoffman ve ark. (2006) tarafından geliştirilen, Meral (2011) tarafından uyarlanan "Beach Center Aile Yaşam Kalitesi Ölçeğinin" orijinal ve normal gelişim gösteren çocuğa sahip ailelere uyarlanmış formu kullanılmıştır. Bulgular, gelişimsel yetersizliğe sahip çocuklu ebeveynlerin aile yaşam kalitesi algılarının normal gelişen çocuklu ebeveynlerden daha düşük olduğunu göstermektedir. Örneklem grupları ölçeğin alt boyutlarında karşılaştıııldığında; gelişimsel yetersizlik gösteren çocukların anne-babaları ebeveynlik boyutunda normal gelişen çocuk anne-babalarından daha düşük, aile etkileşimi boyutunda ise daha yüksek puanlar almışlardır. Farklı tanı grupları karşılaştırıldığında, otizm ve Down sendromlu çocuklu anne-babaların yaşam kalitesi algıları normal gelişen çocuklu annebabalara göre anlamlı derecede düşük bulunmuştur. Zihinsel yetersizliğe sahip çocuklu babaların yaşam kalitesi algılarının normal gelişen çocuklu babalara kıyasla anlamlı derecede düşük olduğu bulunmuşken, annelerde bir farka rastlanmamıştır. Diğer tanı grupları ile ise anlamlı bir farklılık bulunamamıştır. Örneklem gruplarının ölçeğin toplam puanlarında demografik değişkenler açısından anlamlı olarak farklılaşıp farklılaşmadığına bakıldığında yalnızca eğitim düzeyinin aile yaşam kalitesi puanları üzerinde bir etki olduğu gözükmektedir. Araştırma sonucunda gelişimsel yetersizliğe sahip çocuğu olan anne-baba ve kardeşlere psikolojik ve sosyal desteğin arttırılmasının önemli olduğu düşünülmektedir.
\end{abstract}

Anahtar Kelimeler: Aile, Yaşam Kalitesi, Aile Yaşam Kalitesi, Gelişimsel Yetersizlik

Sorumlu Yazar: aORCID:0000-0002-4910-7875 psk.handekaraduman@gmail.com

'Bu çalışma, Hande Karaduman'ın, Doç. Dr. Hanifi Parlar danışmanlığında İstanbul Ticaret Üniversitesi Sosyal Bilimler Enstitüsünde yaptığı lisansüstü tezinden üretilmiştir.
bDoç. Dr., İstanbul Ticaret Üniversitesi, İnsan ve Toplum Bilimleri Fakültesi, İstanbul, Türkiye, Email: hparlar@ticaret.edu.tr

ORCID: 0000-0002-6313-6955

Atıf: Karaduman, H. ve Parlar, H. (2020). Gelişimsel yetersizliğe sahip çocuğu olan ve normal gelişim gösteren çocuğa sahip ebeveynlerin aile yaşam kalitesi algılarının incelenmesi. İZ̈̈ Eğitim Dergisi, 2 (3) 101-121. 


\title{
The examınation of the family life quality perceptions of parents who have children with developmental disability and normal developed child
}

\author{
Hande KARADUMANa
}

Hanifi PARLAR

\begin{abstract}
The aim of the study is to examine family quality of life of parents who have normally developed children and parents who have children with developmental disabilities. The data set was completed by 291 parents in total where 223 parents who have children by developmental disabilities living in Istanbul and 68 parents who have children with normal development. In the study, the data were collected by "Personal Information Form" and "Beach Center Family Quality of Life Scale" which were developed by Hoffman et al. (2006), adapted from Meral (2011) and was adapted to families with children who were original and normal development. The findings show that parents who have children with developmental disabilities have lower perceptions of family life quality than parents who have normally developed children. Once the sample groups are compared in the sub-dimensions of the scale; The mothers of children with developmental disabilities scored lower in terms of the parenting and motional competency dimensions rather than the mothers of normal developed children and they made higher score about family interaction dimension. The fathers of children with developmental disabilities, regarding parenthood they scored lower than their normally developed child's fathers and they scored higher in terms of the family interaction dimension. While different diagnostic groups are compared, the perception of quality of life of parents who have children with autism and Down syndrome was significantly lower than that of parents who have normally developed children. While the perceptions of the life quality of fathers who have children with mental disabilities were found to be significantly lower if we compare to fathers with normally developing children, there was no difference in terms of mothers. No significant difference was found with other diagnostic groups. Once the family life quality scale total scores of parents who have children with developmental disabilities and parents who have normally developed children are examined, it can be seen that there is only an effect on the family life quality scores that is the education level. As a result of the research, it is considered important to increase the psychological and social support to parents and siblings who have children with developmental disabilities.
\end{abstract}

Keywords: Family, Quality of Life, Developmental Disability

This study, Hande Karaduman, Doç. Dr. Hanifi Parlar under the supervision of Istanbul Commerce University Institute of Social Sciences was produced from a part of her graduate thesis. ${ }^{a}$ Corresponding Autor: ORCID:0000-0002-4910-7875

E-mail: psk.handekaraduman@gmail.com
To cite this article: Karaduman, H. \& Parlar, H. (2020). The examination of the family life quality perceptions of parents who have children with developmental disability and normal developed child. IZU Journal of Education, 2 (3) 101-121. 


\section{Extended Abstract}

\section{Introduction}

Family; In many countries, it is defined as the system in which a child spends the longest time in both physical and social development (Aldersey, 2012). Individuals acquire skills such as belonging, loving, being loved, sharing interpersonal, respect, social adaptation within the family system, and when these skills are acquired in a healthy way, individuals continue their lives healthier (Y1ld1z, 2009). The first thing that comes to mind when it comes to developmental disability is the lag and problems experienced in the developmental characteristics that should occur at all ages. These delays are difficult and continuous to improve. For this reason, parents also have more difficulty in meeting the needs of the child compared to the parents who have normal development. Increasing education, health and similar costs due to the child's developmental disability, difficulties in the care of the child, and uncertainties about the future life of the child force parents much more (Görgü, 2005).

Family involvement of the child who has disability affects all the members of the family, it changes the whole order that the family gets used to it, it makes difficult to re-order for all family members (Ahmetoğlu, 2004). Parents with children with developmental disabilities also experience emotional difficulties. Generally, these parents may experience moods such as sadness, shame, anger, guilt, feeling of inadequacy in parents, rejection of child with disability and anxiety (Küçüker, Ceber-Bakkaloğlu, Sucuoğlu, 2001). According to the World Health Organization, quality of life is explained as how individuals perceive their lives and their goals within their cultural norms (World Health Organization QoL Group, 1999). This definition is addressed in six sub-dimensions: physical and psychological well-being, level of independence, social relationships, environmental factors and spirituality (Seed and Lloyd, 1997). Family quality of life is defined as fulfilling the needs of family members, living together as a family, having a goal is meaningful for family members and achieving this goal and satisfaction with all of them (Beach Center on Families and Disability, 2006).

When the literature is analyzed, it is seen that the relevant studies are mostly done in the light of the information received from the mothers, since the task of caring for the child in our country is attributed to the mother as compared to the father. It is assumed that it will be beneficial to practice studies. It is thought that the findings obtained from the study will contribute to the literature in this respect, especially considering the low number of studies on fathers' perceptions of family life quality. For this reason, it is assumed that this study will enrich the findings of the family life qualities of the parents of both children with developmental disabilities and normal development.

The purpose of this study was to examine the quality of life of parents with normal developing children and parents with children who have developmental disabilities. In addition, the aim of the study is the comparison between the parents of children who have normal development and the parents of children who have developmental disabilities is made in the context of the quality of life variable.

\section{Method}

In the study, the causal-comparison model was used. The situation investigated in causal comparison studies is a situation that occurred independently of the manipulator of the 
researcher. If the subjects are to be separated from those affected by the situation and those that are not affected for comparison in a research situation, this distinction occurs spontaneously in the natural development of the situation. (Karasar, 2012).

A total of 291 mothers and fathers completed the data set by 223 parents and children with developmental disabilities, 68 parents and children with normal development. In this study, data were collected in Istanbul. In the study, the data were collected by "Personal Information Form" and "Beach Center Family Quality of Life Scale" which were developed by Hoffman et al. (2006), adapted from Meral (2011) and was adapted to families with children who were original and normal development.

Data were analyzed by SPSS 22 application. While the data analysis of the study was done, parametric methods were used because the data met the normality norms. Independent Sample T Test, One-Way Variance Analysis and Two-Way Variance Analysis were performed for differences between groups. In terms of reliability of the results, evaluation was made considering the significance level of $\mathrm{p}<0.05$ in the 95 percent confidence interval.

\section{Findings and Discussion}

The findings of the study show that the perception of family life quality of parents with children who have developmental disabilities is lower than those of children who have normal development. When the parents of children who have developmental disabilities and parents with children who have normal development were compared in the sub-dimensions of the family quality of life scale (family interaction, parenting, emotional competence, physical / financial / material competence); the mothers of children with developmental disability scored lower in the parenting and emotional competence sub-dimensions than the mothers of children who have normal development and higher in the family interaction sub-dimension. On the other hand, the fathers of the children who have developmental disability scored lower than the fathers of the children who have normal development only in the parenting subdimensions. They scored higher in the family interaction sub-dimension like mothers. Another finding of the study was to examine the family life quality perceptions of children with normal diagnosis and different diagnostic groups (mental disability, autism spectrum disorder, Down syndrome, specific learning disability and cerebral palsy) and the parents of children with Autism and Down syndrome, it was concluded that the quality of life perceptions were significantly lower than the parents with normal developing children. There was no significant difference in the quality of life perceptions of mothers with mental disability children compared to mothers with normal developing children. It was found that fathers with mental disability children had a lower perception of quality of life than fathers with normally developing children. There was no significant difference with other diagnostic groups. Another question of the study is the family quality of life and sub-dimension perceptions of the parents of children with normal diagnosis and different developing groups; There was a significant difference in all sub-dimensions (family interaction, parenting, emotional competence (mother only), physical / financial / material competence, and support for disability) except for the fathers' emotional competence subscale scores.

In another question of the study, it was examined whether there was a significant difference in the demographic variables (socioeconomic level, education level, support from spouse, type of support received, number of children, working status) of the total quality of life scale and the scores of the parents with developmental disabilities and the parents with normal 
developmental children. When the mother with a child who have developmental disability and the level of mother with a normal developing child and the education level of the mothers are considered together, these variables seem to have an effect on the quality of life together. When the father of child who has developmental disability and father of child who has normal development and the education level of the fathers are taken together, it is seen that these variables do not have an effect on the quality of life together. When the findings of the study regarding the socioeconomic level and the number of children in the family are examined, when the parents of children who have developmental disabilities and the parents of children who have normal development and the socioeconomic level of parents and the number of children the family has, variables do not seem to have any effect on the quality of life scores. As the mothers have working status, the mothers support from their husbands and the type of this support are examined, it is seen that the average scores of family mothers with normal development and developmental disability do not differ significantly in terms of total quality of life.

As a result of the research, it is considered important to increase the psychological and social support to parents and siblings who have children with developmental disabilities. As a further suggestion for implementation, families can be provided a little more comfortable by creating care centers where parents can safely entrust their children so that they can spend more time. Considering that families who have difficulties due to similar problems come together, they can understand each other better with empathy, and it is thought that forming a community such as "self-help groups", which have many examples today, may also facilitate the difficulties that parents face.

\section{Giriş}

Gelişimsel yetersizlik denince akla gelenlerden ilki her yaşın evresinde gerçekleşen gelişim özelliklerinde yaşanan gecikme ve problemlerdir. Bu gecikmeler iyileştirilmesi zor ve sürekli durumlardır. Bu nedenle anne-babalar da çocuğun ihtiyaçlarını yerine getirmede normal gelişim gösteren çocuğa sahip anne-babalara kıyasla daha fazla güçlük yaşamaktadırlar. Çocuğun gelişimsel yetersizliğinden kaynaklı giderek artan eğitim, sağlık vb. masraflar, çocuğun bakımında yaşanabilecek güçlükler, çocuğun ileriki yaşantısı ile ilgili belirsizlikler anne-babaları çok daha fazla zorlamaktadır (Görgü, 2005). Yetersizliğe sahip çocuğun aileye katılımı, ailedeki tüm fertleri etkilemekte, ailenin alıştığı tüm düzeni değiştirmekte ve tekrar bir düzen oturtmayı tüm aile fertleri için zorlaştırmaktadır (Ahmetoğlu, 2004). Gelişimsel yetersizliğe sahip çocuğu olan anne-babalar duygusal anlamda da güçlükler yaşamaktadır. Genellikle bu ebeveynlerde üzüntü, çocuktan dolayı duyulan utanç, kızgınlık, suçluluk, ebeveynlikte yetersizlik hissi, yetersizliğe sahip çocuğu reddetme ve kaygı gibi duygudurumlar görülebilmektedir (Küçüker, Ceber-Bakkaloğlu, Sucuoğlu, 2001).

Dünya Sağlık Örgütüne göre yaşam kalitesi, bireylerin kültürel normları içerisinde hayatlarını ve hayatlarındaki gayelerini nasıl algıladıkları şeklinde açıklanmaktadır (World Health Organization QoL Group (WHOQOL), 1999). Bu tanım fiziksel ve psikolojik iyi oluş, bağımsızlık seviyesi, sosyal ilişkiler, çevresel faktörler ve maneviyatla ilgili özellikler olmak üzere altı alt boyutla ele alınmaktadır (Seed ve Lloyd, 1997). Aile yaşam kalitesi ise, aile üyelerinin gereksinimlerinin giderilmesi, bir aile olarak hep beraber yaşamlarını sürdürme, aile üyeleri için anlamı olan bir gayeye sahip olma ve bu gayeye ulaşma ve tüm bunlardan aldıkları doyum şeklinde tanımlanmaktadır (Beach Center on Families and Disability, 2006). Literatür incelendiğinde bu zamana kadar yapılan çalışmalardan elde edilen bulgular aile 
yaşam kalitesini etkileyen faktörlerin; aile etkileşimi, ebeveynlik, duygusal iyilik hali, fiziksel iyilik hali ve engele yönelik destek olduğunu ortaya çıkarmaktadır (Turnbull ve ark., 2003).

Aile yaşam kalitesini belirleyici etmenler incelendiğinde; ailenin sosyoekonomik düzeyi, eğitim seviyesi, anne-babanın çalışıp çalışmadığı ve iş imkanlarının nasıl olduğu, ulaşım ve barınma gibi imkanlar, aile üyelerinin dinlenme, eğlenme ve kendilerine zaman ayırma fırsatlarının ne kadar olduğu gibi etmenler görülmektedir (Canarslan ve Ahmetoğlu, 2015). Kişinin diğer aile fertleri ile beraber keyifli ve kaliteli vakit geçirmesi, hayatlarında var olan sorunlara ailecek hep birlikte çözüm aranması, aile fertlerinin birbirlerine yakınlığı ve bağlılığı, ailede bireylere çeşitli konularda sağlanılan koşullar aile yaşam kalitesinin önemli belirleyicileridir (Andrews ve Withey, 1976; Campbell, Converse ve Rodgers, 1976; akt. Özmete, 2010). Sağlık imkanlarından yeteri kadar faydalanabilme, bir işte çalışma ve meslek sahibi olma ve maddi yönden iyi oluş da aile yaşam kalitesini ele alırken önemli olan faktörler içinde gösterilmektedir. Bu faktörlerde sosyo-ekonomik açıdan farklılıklar olması durumunda, ailelerin yaşam kalitesi düzeyini etkileyebileceği tahmin edilmektedir (Poston ve ark. 2003).

Gelişimsel yetersizliğe sahip çocuklar ve anne-babaları için yapılan çalışmaların en önemli amaçlarından biri ebeveynlerin yaşam doyumlarını yükseltmektir. Çünkü yaşam doyumları arttığında çocuklarına daha faydalı olacakları düşünülmektedir (Milgram ve Atzil, 1988). Bu bağlamda anne-babaların yaşam kalitesi algılarını artırmak için maddi refah, sağlık koşulları, aile fertlerinin birbiriyle ilişkisi, birbirlerinden aldıkları destek, gelişimsel yetersizliğe sahip bireye yardım etme gibi boyutlarla ilgilenilmektedir (Hoffman ve ark., 2006). Alanyazın incelendiğinde, ülkemizde çocuğa bakım verme görevi babaya kıyasla daha çok anneye atfedildiği için ilgili çalışmaların çoğunlukla annelerden alınan bilgiler 1şığında yapıldığı görülmektedir. Bu çalışmalar ailelerin yaşam kalitesi ile ilişkili olabilecek değişkenleri ölçmeye yönelik yapılsa da birçok tanı grubunun ve ebeveynlerden babanın da çalışmaya katıldığı çok az çalışmaya rastlanmıştır. Bu nedenle bu çalışmada gelişimsel yetersizliği olan ve normal gelişim gösteren çocuğa sahip babalar da çalışmaya dahil edilmiştir ve hem annenin aile yaşam kalitesi algısı hem de babanın aile yaşam kalitesi algısına bakılmıştır. Ayrıca daha fazla tanı grubu çalışmaya dahil edilerek çocuğun tanısına göre aile yaşam kalitesi toplam ve alt boyut puanlarında farklılaşma olup olmadığına bakılması çalışmanın amaçlarından bir diğeridir. Dolayısıyla bu araştırmanın hem gelişimsel yetersizlik gösteren hem de normal gelişim gösteren çocukların hem anne hem de babalarının aile yaşam kalitesi algılarını göstererek hem literatüre hem de uygulamaya yönelik çalışmalara faydası olacağ1 varsayılmaktadır. Özellikle babaların aile yaşam kalitesi algılarına ilişkin yapılan çalışmaların azlığ1 düşünüldüğünde çalışmadan elde edilen bulguların literatüre bu yönden katkı sağlayacağı düşünülmektedir.

\section{Yöntem}

$\mathrm{Bu}$ araştırmada, gelişimsel yetersizliği olan çocuk ebeveynlerinin ve normal gelişim gösteren çocuğa sahip ebeveynlerin aile yaşam kalitelerini belirlemek amacıyla nicel araştırma desenlerinden nedensel-karşılaştırma modeli kullanılmıştır.

\section{Evren ve Örneklem}

Araştırmanın evrenini, Türkiye'nin İstanbul ilinde gelişimsel yetersizliğe sahip çocuğu olan ve bu çocuğu Milli Eğitim Bakanlığı'na bağlı özel eğitim ve rehabilitasyon merkezlerinde 
bireysel eğitim alan anne-babalar oluşturmaktadır. Bu araştırmaya ise, gelişimsel yetersizliğe sahip çocuğu olan 223 anne-baba ve çocuğu normal gelişim gösteren 68 anne-baba olmak üzere toplamda 291 anne ve baba katılmıştır. Araştırmada örneklem gelişimsel yetersizliğe sahip çocuğu olan anne-babalar seçilirken amaçlı örneklem olarak seçilmiştir. Örneklem grubunu İstanbul ili Eyüp ve Fatih ilçelerinde bulunan Milli Eğitim Bakanlığı'na bağlı özel eğitim ve rehabilitasyon merkezlerinde en az 1 yıldır eğitim alan 223 çocuk ve anne-babaları oluşturmaktadır. Normal gelişim gösteren çocuk anne-babalarından veri toplanırken İstanbul için kartopu örneklem yöntemi kullanılmıştır. Araştırmaya katılan ebeveynlerin demografik özelliklerine ilişkin bilgiler Tablo 1'de verilmiştir.

Tablo 1. Normal Gelişen Çocuğa Sahip Ailelerin Demografik Özellikleri

\begin{tabular}{|c|c|c|c|}
\hline & Gruplar & $f$ & $\%$ \\
\hline \multirow{5}{*}{$\begin{array}{l}\text { Annenin } \\
\text { Düzeyi }\end{array}$} & İlkokul & 2 & 2,9 \\
\hline & Ortaokul & 16 & 23,5 \\
\hline & Lise & 30 & 44,1 \\
\hline & Üniversite & 18 & 26,5 \\
\hline & Yüksek Lisans- Doktora & 2 & 2,9 \\
\hline \multirow{5}{*}{$\begin{array}{l}\text { Babanın } \\
\text { Düzeyi }\end{array}$} & İlkokul & 2 & 2,9 \\
\hline & Ortaokul & 11 & 16,2 \\
\hline & Lise & 40 & 52,9 \\
\hline & Üniversite & 15 & 22,1 \\
\hline & Yüksek Lisans- Doktora & 4 & 5,9 \\
\hline \multirow{3}{*}{ Medeni Durum } & Evli & 63 & 92,6 \\
\hline & Boşanmış & 3 & 4,4 \\
\hline & Dul & 2 & 2,9 \\
\hline \multirow{5}{*}{$\begin{array}{l}\text { Sosyo-Ekonomik } \\
\text { Düzey }\end{array}$} & Alt & 7 & 10,3 \\
\hline & Orta-alt & 25 & 36,8 \\
\hline & Orta & 13 & 19,1 \\
\hline & Orta-üst & 15 & 22,1 \\
\hline & Üst & 8 & 11,8 \\
\hline \multirow{5}{*}{ Çocuk Sayısı } & Tek Çocuk & 21 & 30,9 \\
\hline & 2 & 29 & 42,6 \\
\hline & 3 & 17 & 23,5 \\
\hline & 4 & 1 & 1,5 \\
\hline & 5 ve üzeri & 1 & 1,5 \\
\hline Babadan & Evet & 58 & 85,3 \\
\hline Bakım Desteği & Hayır & 10 & 14,7 \\
\hline \multirow{4}{*}{$\begin{array}{l}\text { Bakım } \\
\text { Türü }\end{array}$} & Destek Almayan & 10 & 14,7 \\
\hline & Maddi Destek Sağlamak & 30 & 44,1 \\
\hline & Bakımına Yardım Etmek & 28 & 41,2 \\
\hline & Toplam & 68 & 100.0 \\
\hline
\end{tabular}

Katılımcılardan normal gelişim gösteren çocuğa sahip annelerin çoğu $(\% 44,1)$ lise ve $(\% 26)$ ortaokul mezunu, büyük çoğunluğu $(\% 92,6)$ ise evli olduğunu belirtmiştir. Katılımcılardan babaların eğitim düzeyine bakıldığında ise çoğunun $(\% 52,9)$ lise ve $(\% 22,1)$ üniversite mezunu olduğu görülmektedir. Katılımcıların sosyo-ekonomik gelir düzeylerine ilişkin bilgi elde etmek amaciyla sorulan soruya verdikleri yanttlardan, $7^{\prime} \operatorname{sinin}(\% 10,3)$ alt, $25^{\prime}$ inin $(\% 36,8)$ ortaalt, 13'ünün $(\% 19,1)$ orta, $15^{\prime}$ inin $(\% 22,1)$ orta-üst ve $8^{\prime}$ inin $(\% 11,8)$ üst sosyo-ekonomik duruma sahip olduğu görülmüştür. Katılımcılar çocuk sayısı açısından değerlendirildiğinde 
$21^{\prime}$ inin $(\% 30,9)$ tek, 29'unun $(\% 42,6)$ iki, 16'sının $(\% 23,5)$ üç, 1'inin $(\% 1,5)$ dört ve 1 kişinin de $(\% 1,5) 5$ ve üzeri çocuğa sahip olduğu saptanmıştır. Katılımcıların büyük çoğunluğu $(\% 85,3)$ eşinden çocuğun bakımı ile ilgili destek gördüğünü, bu desteğin de $(\% 42,6)$ maddi destek sağlamak ve $(\% 41,2)$ çocuğun bakımına yardım etmek olduğunu ifade etmiştir.

Tablo 2. Gelişimsel Yetersizliğe Sahip Çocuğu Olan Ailelerin Demografik Özellikleri

\begin{tabular}{|c|c|c|c|}
\hline & Gruplar & $f$ & $\%$ \\
\hline \multirow{6}{*}{$\begin{array}{l}\text { Annenin Eğitim } \\
\text { Düzeyi }\end{array}$} & Okuma Yazma Yok & 2 & 0,9 \\
\hline & İlkokul & 51 & 22,9 \\
\hline & Ortaokul & 43 & 19,3 \\
\hline & Lise & 96 & 43,0 \\
\hline & Üniversite & 30 & 13,5 \\
\hline & Yüksek Lisans- Doktora & 1 & 0,4 \\
\hline \multirow{6}{*}{$\begin{array}{l}\text { Babanın Eğitim } \\
\text { Düzeyi }\end{array}$} & Okuma Yazma Yok & 1 & 0,4 \\
\hline & İlkokul & 28 & 12,6 \\
\hline & Ortaokul & 72 & 32,3 \\
\hline & Lise & 89 & 39,9 \\
\hline & Üniversite & 32 & 14,3 \\
\hline & Yüksek Lisans- Doktora & 1 & 0,4 \\
\hline \multirow{2}{*}{ Medeni Durum } & Evli & 218 & 97,8 \\
\hline & Boşanmış & 3 & 2,2 \\
\hline \multirow{5}{*}{$\begin{array}{l}\text { Sosyo-Ekonomik } \\
\text { Düzey }\end{array}$} & Alt & 42 & 18,8 \\
\hline & Orta-alt & 78 & 35,0 \\
\hline & Orta & 86 & 38,6 \\
\hline & Orta-üst & 12 & 5,4 \\
\hline & Üst & 5 & 2,2 \\
\hline \multirow{5}{*}{ Çocuk Sayısı } & Tek Çocuk & 54 & 24,2 \\
\hline & 2 & 108 & 48,4 \\
\hline & 3 & 50 & 22,4 \\
\hline & 4 & 3 & 1,3 \\
\hline & 5 ve üzeri & 8 & 3,6 \\
\hline Babadan Alınan & Evet & 186 & 83,4 \\
\hline \multirow[t]{2}{*}{ Bakım Desteği } & Hayır & 37 & 16,6 \\
\hline & Destek Almayan & 37 & 14,7 \\
\hline \multirow{4}{*}{$\begin{array}{l}\text { Bakım } \\
\text { Türü }\end{array}$} & Rehabilitasyona Götürmek & 24 & 10,8 \\
\hline & Maddi Destek Sağlamak & 75 & 33,6 \\
\hline & Bakımına Yardım Etmek & 87 & 39,0 \\
\hline & Toplam & 223 & 100.0 \\
\hline
\end{tabular}

Katılımcılardan gelişimsel yetersizliğe sahip çocuğu olan annelerin çoğu $(\% 43,0)$ lise ve $(\% 22,9)$ ilkokul mezunu, büyük çoğunluğu $(\% 97,8)$ ise evli olduğunu belirtmiştir. Katılımcılardan babaların eğitim düzeyine bakıldığında ise çoğunun $(\% 39,9)$ lise ve $(\% 32,3)$ ortaokul mezunu olduğu görülmektedir.

Katılımcıların sosyo-ekonomik gelir düzeylerine ilişkin bilgi elde etmek amacıyla sorulan soruya verdikleri yanitlardan, $42^{\prime} \operatorname{sinin}(\% 18,8)$ alt, 78'inin $(\% 35,0)$ orta-alt, 86'sinin $(\% 38,6)$ orta, 12 'sinin $(\% 5,4)$ orta-üst ve $5^{\prime}$ inin $(\% 2,2)$ üst sosyo-ekonomik duruma sahip olduğu görülmüş̧ür. Katılımcılar çocuk sayısı açısından değerlendirildiğinde 54 'ünün $(\% 24,2)$ tek, 
$108^{\prime}$ inin $(\% 48,4)$ iki, 50'sinin $(\% 22,4)$ üç, 3'ünün $(\% 1,3)$ dört ve 8 kişinin de $(\% 3,6) 5$ ve üzeri çocuğa sahip olduğu saptanmıştır.

Katılımcıların büyük çoğunluğu $(\% 83,4)$ eşinden çocuğun bakımı ile ilgili destek gördüğünü, bu desteğin de $(\% 39,0)$ bakımına yardım etmek, $(\% 33,6)$ maddi destek sağlamak ve $(\% 10,8)$ rehabilitasyona götürmek olduğunu ifade etmiştir.

\section{Veri Toplama Araçları}

Araştırmada veri toplama aracı olarak demografik değişkenleri elde etmek amacıyla "Kişisel Bilgi Formu" ve ebeveynlerin yaşam kalitesini belirlemek için Hoffman ve ark. (2006) tarafından geliştirilen, Meral (2011) tarafından uyarlanan Beach Center Aile Yaşam Kalitesi Ölçeğinin orijinal ve normal gelişim gösteren çocuğa sahip ailelere uyarlanmış formu kullanılmıştır.

Kişisel Bilgi Formu: Formda gelişimsel yetersizliğe sahip çocuğu olan katılımcıların yaş, cinsiyet, medeni durum, eğitim düzeyi, eşlerinin eğitim düzeyi, haftalık çalışma saati, sosyoekonomik düzeyi, ailedeki çocuk sayısı, yetersizliği olan çocuğun yaşı, cinsiyeti ve tanısı, eşten çocuğun bakımı ile ilgili destek bilgilerinin cevaplarının alınmasına ilişkin sorular bulunmaktadır. Normal gelişen çocuğa sahip olan katılımcıların formunda ise yaş, cinsiyet, medeni durum, eğitim düzeyi, eşlerinin eğitim düzeyi, haftalık çalışma saati, sosyoekonomik düzeyi, eşten çocuğun bakımı ile ilgili destek bilgilerinin cevaplarının alınmasına ilişkin sorular bulunmaktadır.

Beach Center Aile Yaşam Kalitesi Ölçeği (BCAYKÖ): Hoffman ve ark. (2006) tarafından geliştirilmiş ve Türk kültürüne uyarlama çalışmaları Meral (2011) tarafından yapılmıştır. Geçerlilik ve güvenilirlik çalışmaları ise 2013 yılında Meral ve Cavkaytar tarafından yapılmıştır.25 maddeden oluşan Beach Center Aile Yaşam Kalitesi Ölçeğinin aile etkileşimi, ebeveynlik, duygusal yeterlik, finansal/fiziksel/materyal yeterliği ve yetersizliğe ilişkin destek olmak üzere 5 alt boyutu bulunmaktadır. Ölçeğin ters maddesi bulunmamaktadır ve ölçekten alınan yüksek puanlar yüksek düzeyde aile yaşam kalitesi algısını, düşük puanlar ise düşük düzeydeki algıyı göstermektedir. Ölçeğin Cronbach alfa iç tutarlılık katsayısı bütün ölçek için .94; aile etkileşimi alt boyutu için .92, ebeveynlik alt boyutu için .88, duyusal yeterlik için .80, finansal/fiziksel/materyal yeterliği için .88, yetersizliğe ilişkin destek alt boyutu için ise .92 olarak bulunmuştur. Ölçek normal gelişen çocuğa sahip ebeveynlere uygulanırken yetersizliğe ilişkin olan sorular çıkarılmış ve ilk 21 madde katılımcılara verilmiştir.

\section{Verilerin Analizi}

Verilerin istatistiksel çözümleme aşamasında, Kişisel Bilgi Formu Bilgileri, Beach Center Aile Yaşam Kalitesi Ölçeğinden elde edilen veriler SPSS 22 programına kayıt edilmiştir. Çalışmanın veri analizi yapılırken veriler normallik sayıltılarını karşıladığı için parametrik yöntemler kullanılmıştır. Gruplar arası farklar için Bă̆ımsız Örneklem T Testi, Tek Yönlü Varyans Analizleri ve Çift Yönlü Varyans Analizleri yapılmıştır. Sonuçların güvenirliliği açısında yüzde 95 güven aralığında, $\mathrm{p}<0,05$ anlamlılık düzeyin dikkate alınarak değerlendirme yapılmıştır.

\section{Bulgular}

Bu bölümde ilk olarak katılımcılardan elde edilen verilerin parametrik analizlere uygun olup olmadığı sınanmıştır ve çalışmanın amacına yönelik yapılan analiz sonuçları tablo ve açıklama halinde sunulup yorumlanmıştır. 


\section{Gelişimsel Yetersizlik ve Normal Gelişim Gösteren Çocukların Annelerinin Aile Yaşam Kalitelerine İlişkin Bulgular}

Annelerin normal gelişim gösteren ve gelişimsel yetersizliğe sahip çocuğu olma durumuna göre Aile Yaşam Kalitesi toplam ve alt boyut puan ortalamaları arasında anlamlı bir fark olup olmadığını belirlemek amacıyla bağımsız gruplar t-testi analizi uygulanmıştır. Uygulanan analiz sonuçlarına göre iki gruptaki aile yaşam kalitesi aile etkileşimi, ebeveynlik, duygusal yeterlik alt boyut ve toplam puan ortalamalarının anlamlı derecede farklılaştığı saptanmıştır [sırasıyla: $\mathrm{t}(289)=-2,75, \mathrm{p}<.01 ; \mathrm{t}(289)=4,08, \mathrm{p}<.01 ; \mathrm{t}(289)=3,43, \mathrm{p}<.01 ; \mathrm{t}(289)=2,94, \mathrm{p}<.01]$. İki grubun da annelerinin fiziksel/finansal/materyal yeterliği alt boyut puan ortalamalarına bakıldığında anlamlı bir farklılık olmadığ sonucuna ulaşılmıştır [t (289) =1,02, p> .05].

Tablo 3. Annelere Göre Aile Yaşam Kalitesi Toplam ve Alt Boyut Puan Ortalamalarının Farklılaşmasına İlişkin T- testi Analizi Sonuçları

\begin{tabular}{|c|c|c|c|c|c|c|}
\hline & $\mathbf{N}$ & Ort & Ss & df & $\mathbf{t}$ & $\mathbf{p}$ \\
\hline \multicolumn{7}{|l|}{ Aile Etkileşimi } \\
\hline Normal Gelişim Gösteren & 68 & 22,57 & 2,79 & 289 & $-2,75$ &, $001^{* *}$ \\
\hline Gelişimsel Yetersizliği Olan & 223 & 23,56 & 1,77 & & & \\
\hline \multicolumn{7}{|l|}{ Fiziksel/Finansal/ Materyal } \\
\hline Normal Gelişim Gösteren & 68 & 18,07 & 4,46 & 289 & 1,02 & ,307 \\
\hline Gelişimsel Yetersizliği Olan & 223 & 17,35 & 5,24 & & & \\
\hline \multicolumn{7}{|l|}{ Duygusal Yeterlik } \\
\hline Normal Gelişim Gösteren & 68 & 15,31 & 2,02 & 289 & 3,43 &, $001^{* *}$ \\
\hline Gelişimsel Yetersizliği Olan & 223 & 14,30 & 2,14 & & & \\
\hline \multicolumn{7}{|l|}{ Ebeveynlik } \\
\hline Normal Gelişim Gösteren & 68 & 26,32 & 2,58 & 289 & 4,08 &, $000^{* *}$ \\
\hline Gelişimsel Yetersizliği Olan & 223 & 25,04 & 2,17 & & & \\
\hline \multicolumn{7}{|l|}{ Toplam } \\
\hline Normal Gelişim Gösteren & 68 & 97,95 & 10,32 & 289 & 2,94 & $.004^{* *}$ \\
\hline Gelişimsel Yetersizliği Olan & 223 & 93,95 & 7,99 & & & \\
\hline
\end{tabular}

$* p<.05, * * p<.01$

Uygulanan analiz sonuçlarına göre normal gelişim gösteren çocuk annelerinin aile etkileşimi alt boyut puan ortalamalarının ( $\left.\mathrm{X}_{\text {ort. }}=22,57, \mathrm{~s}=2,79\right)$, gelişimsel yetersizliği olan çocuk annelerinden ( $\left.X_{\text {ort. }}=23,56, s=1,77\right)$ anlamlı derecede düşük olduğu bulunmuştur. Ebeveynlik alt boyutuna bakıldığında, normal gelişim gösteren çocuğa sahip annelerin puan ortalamalarının ( $\left.X_{\text {ort. }}=26,32, \mathrm{~s}=2,58\right)$, gelişimsel yetersizliği olan çocuk annelerinden ( $X_{\text {ort }}$ $=25,04, s=2,17$ ) anlamlı derecede yüksek çıkmıştır. Benzer şekilde, duygusal yeterlik alt boyutuna bakıldığında normal gelişim gösteren çocuk annelerinin puan ortalamaları ( $X_{\text {ort. }}$ $=15,31, \mathrm{~s}=2,02)$, gelişimsel yetersizliği olan çocuk annelerinden $\left(X_{\text {ort. }}=14,30, \mathrm{~s}=2,14\right)$ anlaml derecede yüksek bulunmuştur. Ayrıca normal gelişim gösteren çocuk annelerinin toplam puan ortalamalarının da $\left(X_{\text {ort. }}=97,95, s=10,32\right)$, gelişimsel yetersizliği olan çocuk annelerinkinden $\left(X_{\text {ort }}=93,95, s=7,99\right)$ anlamlı derecede yüksek olduğu bulunmuştur. 


\section{Gelişimsel Yetersizlik ve Normal Gelişim Gösteren Çocukların Babalarının Aile Yaşam Kalitelerine İlişkin Bulgular}

Babaların normal gelişim gösteren ve gelişimsel yetersizliğe sahip çocuğu olma durumuna göre Aile Yaşam Kalitesi toplam ve alt boyut puan ortalamaları arasında anlamlı bir fark olup olmadığını belirlemek amacıyla bağımsız gruplar t-testi analizi uygulanmıştır. Uygulanan analiz sonuçlarına göre iki gruptaki aile yaşam kalitesi aile etkileşimi, ebeveynlik ve toplam puan ortalamalarının anlamlı derecede farklılaştığı saptanmıştır [sırasıyla: t $(289)=-4,27, \mathrm{p}<.01 ; \mathrm{t}$ $(289)=12,79, \mathrm{p}<.01 ; \mathrm{t}(289)=4,32, \mathrm{p}<.01 ; \mathrm{t}(289)=2,94, \mathrm{p}<.01]$. İki grubun da babalarının fiziksel/finansal/materyal yeterliği ve duygusal yeterlik alt boyut puan ortalamalarına bakıldığında anlamlı bir farklılık olmadığı sonucuna ulaşılmıştır [t (289) =1,33, p> .05; t (289) $=1,42, \mathrm{p}>.05]$.

Tablo 4. Babalara Göre Aile Yaşam Kalitesi Toplam ve Alt Boyut Puan Ortalamalarının Farklılaşmasına İlişkin T- testi Analizi Sonuçları

\begin{tabular}{|c|c|c|c|c|c|c|}
\hline & $\mathbf{N}$ & Ort & Ss & df & $\mathbf{t}$ & $\mathrm{p}$ \\
\hline \multicolumn{7}{|l|}{ Aile Etkileşimi } \\
\hline Normal Gelişim Gösteren & 68 & 21,96 & 2,50 & 289 & $-4,28$ &, $001^{* *}$ \\
\hline Gelişimsel Yetersizliği Olan & 223 & 23,35 & 1,80 & & & \\
\hline \multicolumn{7}{|l|}{$\begin{array}{ll}\text { Fiziksel/Finansal/ } & \text { Materyal } \\
\text { Yeterliği } & \end{array}$} \\
\hline Normal Gelişim Gösteren & 68 & 17,99 & 4,35 & 289 & 1,33 & ,184 \\
\hline Gelişimsel Yetersizliği Olan & 223 & 17,10 & 5,00 & & & \\
\hline \multicolumn{7}{|l|}{ Duygusal Yeterlik } \\
\hline Normal Gelişim Gösteren & 68 & 15,95 & 1,75 & 289 & 1,42 & ,157 \\
\hline Gelişimsel Yetersizliği Olan & 223 & 15,58 & 2,10 & & & \\
\hline \multicolumn{7}{|l|}{ Ebeveynlik } \\
\hline Normal Gelişim Gösteren & 68 & 26,69 & 1,65 & 289 & 12,79 &, $000^{* *}$ \\
\hline Gelişimsel Yetersizliği Olan & 223 & 23,44 & 2,34 & & & \\
\hline \multicolumn{7}{|l|}{ Toplam } \\
\hline Normal Gelişim Gösteren & 68 & 98,25 & 8,26 & 289 & 4,32 & $.000^{* *}$ \\
\hline Gelişimsel Yetersizliği Olan & 223 & 93,43 & 8,00 & & & \\
\hline
\end{tabular}

${ }^{*} p<.05,{ }^{* *} p<.01$

Uygulanan analiz sonuçlarına göre gelişimsel yetersizliği olan çocuk babalarının aile etkileşimi alt boyut puan ortalamalarının $\left(X_{\text {ort. }}=23,35, \mathrm{~s}=1,80\right)$, normal gelişim gösteren çocuk babalarından ( $\left.X_{\text {ort. }}=21,96, s=2,50\right)$ anlamlı derecede yüksek olduğu bulunmuştur. Ebeveynlik alt boyutuna bakıldığında, normal gelişim gösteren çocuğa sahip babaların puan ortalamalarının ( $\left.X_{\text {ort. }}=26,69, \mathrm{~s}=1,65\right)$, gelişimsel yetersizliği olan çocuk babalarından ( $X_{\text {ort. }}$. $=23,44, \mathrm{~s}=2,34$ ) anlamlı derecede yüksek çıkmıştır. Ayrıca normal gelişim gösteren çocuk babalarının toplam puan ortalamalarının da $\left(X_{\text {ort }}=98,25, s=8,26\right)$, gelişimsel yetersizliği olan çocuk babalarınınkinden ( $\left.X_{\text {ort. }}=93,42, s=8,00\right)$ anlamlı derecede yüksek olduğu bulunmuştur. 


\section{Normal Gelişen ve Farklı Tanı Gruplarından Olan Çocukların Annelerinin Aile Yaşam Kalitelerine İlişkin Bulgular}

Normal gelişim gösteren çocuk anneleri ile farklı tanı grubundaki çocukların annelerinin aile yaşam kalitesi puan ortalamaları arasında anlamlı bir farklılık olup olmadığın belirlemek amacıyla Tek Yönlü Varyans Analizi (ANOVA) uygulanmıştır. Aile yaşam kalitesi ölçeğinin puanları Kolmogorov-Smirnov test sonuçları incelendiğinde $p$ değeri $(p>0.05)$ toplam ve alt boyut puanlarında normal dağılım gözlenmiştir. Bu nedenle, gruplar arası farkları sınamak amacıyla parametrik yöntem tercih edilmiştir. Analiz sonucunda aile yaşam kalitesi toplam puan ortalamalarının gruplara göre anlamlı düzeyde farklılaşma gösterdiği saptanmıştır [F (5285) $=13,78, p<.05]$. Bu farklılığın hangi gruplarda çıktığını belirlemek amacıyla Post-hoc Tukey analizi uygulanmıştır. Normal gelişim gösteren çocuğa sahip annelerin $\left(X_{\text {ort. }}=97,95, \mathrm{~s}=\right.$ $10,32)$ aile yaşam kalitesi puan ortalamalarının otizmli çocuk $\left(X_{\text {ort. }}=90,44, s=6,17\right)$ ve Down sendromlu olan çocuk ( $X_{\text {ort. }}=88,91, s=10,09$ ) annelerinden anlamlı derecede yüksek olduğu bulunmuştur. Zihinsel yetersizlik, özgül öğrenme güçlüğü ve serebral palsi tanılı çocuğa sahip annelere göre ise anlamlı bir farklılık bulunamamıştır ( $p>.05)$. Gruplara göre annelerin aile yaşam kalitesi toplam puanlarına ilişkin analiz sonucu Tablo 5' de verilmiştir.

Tablo 5. Annelere Göre Aile Yaşam Kalitesi Puan Ortalamalarının Farklılaşmasına İlişkin Varyans, Post-hoc Tukey Analizi Sonuçları

\begin{tabular}{lclllll}
\hline Tanı Grupları & N & Ort. & Ss. & F & p & Tukey \\
\hline Normal Gelişim Gösteren & 68 & 97,95 & 10,32 & 13,78 & $.000^{* *}$ & \\
Zihinsel Yetersizlik & 47 & 95,15 & 6,61 & & & \\
Otizm & 68 & 90,44 & 6,17 & & & Normal $>$ Otizm \\
Down Sendromu & 34 & 88,91 & 10,09 & & & Normal $>$ Down \\
& & & & & \\
Özgül Öğgrenme Güçlüğüu & 42 & 98,14 & 7,09 & & & \\
Serebral Palsi & 32 & 99,47 & 4,91 & & & \\
\hline${ }^{*} p<.05,{ }^{* *} p<.01$ & & & & & &
\end{tabular}

\section{Normal Gelişen ve Farklı Tanı Gruplarından Olan Çocukların Babalarının Aile Yaşam Kalitelerine İlişkin Bulgular}

Normal gelişim gösteren çocuk babaları ile farklı tanı grubundaki çocukların babalarının aile yaşam kalitesi puan ortalamaları arasında anlamlı bir farklılık olup olmadığını belirlemek amacıyla Tek Yönlü Varyans Analizi (ANOVA) uygulanmıştır. Analiz sonucunda aile yaşam kalitesi puan ortalamalarının gruplara göre anlamlı düzeyde farklılaşma gösterdiği saptanmiştır [F (5-285) = 15,89, p<.05].

$\mathrm{Bu}$ farklılığın hangi gruplarda çıtığını belirlemek amacıyla Post-hoc Tukey analizi uygulanmıştır. Normal gelişim gösteren çocuğa sahip babaların (Xort. =98,25, s=1,00) aile yaşam kalitesi puan ortalamalarının zihinsel yetersizliğe sahip çocuk (Xort. =94,08, s=5,33), otizmli çocuk (Xort. $=89,18$, s=7,19) ve Down sendromlu olan çocuk (Xort=90,82, s=9,15) babalarından anlamlı derecede yüksek olduğu bulunmuştur. Özgül öğrenme güçlüğü ve serebral palsi tanılı çocuğa sahip annelere göre ise anlamlı bir farklılık bulunamamıştır ( $\mathrm{p}>.05)$. Gruplara göre babaların aile yaşam kalitesi toplam puanlarına ilişkin analiz sonucu Tablo 6' da verilmiştir. 
Tablo 6. Babalara Göre Aile Yaşam Kalitesi Puan Ortalamalarının Farklılaşmasına İlişkin Varyans, Post-hoc Tukey Analizi Sonuçları

\begin{tabular}{lccccll}
\hline Tanı Grupları & N & Ort. & Ss. & F & p & Tukey \\
\hline Normal Gelişim Gösteren & 68 & 98,25 & 8,26 & 24.65 & $.001^{\text {** }}$ & \\
Zihinsel Yetersizlik & 47 & 94,07 & 5,33 & & & $\begin{array}{l}\text { Normal }>\text { Zihinsel } \\
\text { Yetersizlik }\end{array}$ \\
Otizm & 68 & 89,18 & 7,19 & & Normal $>$ Otizm \\
Down Sendromu & 34 & 90,82 & 9,15 & & Normal $>$ Down \\
Özgül Öğrenme Güçlüğüu & 42 & 97,37 & 7,97 & & & \\
Serebral Palsi & 32 & 99,06 & 5,47 & & & \\
\hline
\end{tabular}

${ }^{*} p<.05,{ }^{* *} p<.01$

\section{Sosyo-demografik Özelliklere Göre Gelişimsel Yetersizlik ve Normal Gelişim Gösteren Çocukların Anne-Babalarının Aile Yaşam Kalitesi Puanlarına İlişkin Bulgular}

Aşağıda aile yaşam kalitesi toplam puanlarının sosyo-demografik değişkenlere göre farklılaşıp farklılaşmamasına ilişkin tablolar sırası ile verilmiştir.

Normal gelişim gösteren ve gelişimsel yetersizliğe sahip olan çocuk annelerinin eğitim düzeylerinin aile yaşam kalitesi toplam puan ortalamalarını istatistiki açıdan anlamlı olarak farklılaştırıp farklılaştırmadığını belirlemek amacıyla çift yönlü varyans analizi uygulanmıştır. Sonuçlar tablo $7^{\prime}$ de görülmektedir. Yapılan analize göre eğitim ( $F=2,89$; $\mathrm{p}=0,090>0.05)$; değişkeninin aile yaşam kalitesi puanları ile arasında anlamlı farklılık bulunmamıştır. Tek başına normal ile gelişimsel yetersizliğe sahip çocuğu olma durumu $(\mathrm{F}=12,39 ; \mathrm{p}=0,001<0.01)$ ve eğitim ve normal ile gelişimsel yetersizliğe sahip çocuğu olma durumu $(\mathrm{F}=4,80 ; \mathrm{p}=0,029<0.05)$, kategorik değişkenlerinin ise aile yaşam kalitesi puanları ile arasında anlamlı farklılık bulunmuştur. Bu bulgu eğitim düzeyi ortaokul ve altı olan gelişimsel yetersizlik gösteren çocuk annelerinin (Xort. $=91,11, \mathrm{~s}=0,85$ ) aile yaşam kalitesi puanları eğitim düzeyi lise ve üstü olan normal gelişim gösteren çocukların annelerinin (Xort. $=97,79, \mathrm{~s}=1,18)$ puanlarından daha düşüktür.

Tablo 7. Eğitim Düzeyine Göre Annelerin Aile Yaşam Kalitesi Toplam Puan Ortalamalarına İlişkin Çift Yönlü Varyans Analizi Sonuçları

\begin{tabular}{lllll}
\hline Varyansın Kaynağı & df & Karelerin ort. & F & p \\
\hline Aile Yaşam Kalitesi & & & & \\
$\begin{array}{l}\text { Normal ya da Gelişimsel yetersizliğe } \\
\text { sahip çocuğu olma durumu }\end{array}$ & 1 & 862,58 & 12,39 &, $001^{* *}$ \\
$\begin{array}{l}\text { Eğitim Düzeyi } \\
\begin{array}{l}\text { Normal ya da Gelişimsel yetersizliğe } \\
\text { sahip çocuğu olma durumu* Eğitim }\end{array}\end{array}$ & 1 & 201,174 & 2,89 &, 090 \\
$\begin{array}{l}\text { Düzeyi } \\
{ }^{*} p<.05,{ }^{* *} p<.01\end{array}$ & 334,05 & 4,80 &, $029^{*}$ \\
\end{tabular}

Normal gelişim gösteren ve gelişimsel yetersizliğe sahip olan çocuk babalarının eğitim düzeylerinin aile yaşam kalitesi toplam puan ortalamalarını istatistiki açıdan anlamlı olarak farklılaştırıp farklılaştırmadığını belirlemek amacıyla çift yönlü varyans analizi uygulanmıştır. Sonuçlar tablo 8 'de görülmektedir. Yapılan analize göre eğitim $(\mathrm{F}=0,18$; $\mathrm{p}=0,670>0.05)$; eğitim ve normal ile gelişimsel yetersizliğe sahip çocuğu olma durumu ( $\mathrm{F}=3,49$; $\mathrm{p}=0,063>0.05)$, kategorik değişkenlerinin aile yaşam kalitesi puanları ile arasında anlamlı 
farklılık bulunmamıştır. Tek başına normal ile gelişimsel yetersizliğe sahip çocuğu olma durumu $(F=17,50 ; p=0,000<0.05)$ değişkeninin, aile yaşam kalitesi puanları ile arasında anlamlı farklılık bulunmuştur.

Tablo 8. Eğitim Düzeyine Göre Babaların Aile Yaşam Kalitesi Toplam Puan Ortalamalarına İlişkin Çift Yönlü Varyans Analizi Sonuçları

\begin{tabular}{lllll}
\hline Varyansın Kaynağı & df & Karelerin ort. & F & p \\
\hline Aile Yaşam Kalitesi & & & & \\
$\begin{array}{l}\text { Normal ya da Gelişimsel yetersizliğe } \\
\text { sahip çocuğu olma durumu }\end{array}$ & 1 & 1111,23 & 17,50 &, $000^{* *}$ \\
$\begin{array}{l}\text { Eğitim Düzeyi } \\
\text { Normal ya da Gelişimsel yetersizliğe } \\
\text { sahip çocuğu olma durumu* Eğitim }\end{array}$ & 1 & 11,53 & 0,18 &, 670 \\
$\begin{array}{l}\text { Düzeyi } \\
{ }^{*} p<.05,{ }^{* *} p<.01\end{array}$ & 221,84 & 3,49 &, 063 \\
\end{tabular}

Normal gelişim gösteren ve gelişimsel yetersizliğe sahip olan çocuk annelerinin sosyoekonomik düzeylerinin aile yaşam kalitesi toplam puan ortalamalarını istatistiki açıdan anlamlı olarak farklılaştırıp farklılaştırmadığını belirlemek amacıyla çift yönlü varyans analizi uygulanmıştır. Sonuçlar tablo $9^{\prime}$ da görülmektedir. Yapılan analize göre sosyo-ekonomik düzey $(\mathrm{F}=123,78 ; \mathrm{p}=0,000<0.01)$ ve normal ile gelişimsel yetersizliğe sahip çocuğu olma durumu $(\mathrm{F}=10,58 ; \mathrm{p}=0,001<0.01)$, kategorik değişkenlerinin aile yaşam kalitesi puanları ile arasında anlamlı farklılık bulunmuştur. Sosyo-ekonomik düzey ve normal ile gelişimsel yetersizliğe sahip çocuğu olma durumu ( $F=3,20 ; p=0,075>0.05)$ değişkeninin, aile yaşam kalitesi puanları ile arasında ise anlamlı farklılık bulunamamıştır. Sosyoekonomik düzey ile ilgili ise orta ve üstü (Xort. $=101,42, \mathrm{~s}=0,68$ ) sosyoekonomik düzey algısına sahip olan annelerin aile yaşam kalitesi algılarının alt ve orta-alt (Xort. $=90,58, \mathrm{~s}=0,70$ ) sosyoekonomik düzey algısına sahip olan annelerden anlamlı derecede daha yüksek olduğu bulunmuştur.

Tablo 9. Sosyo-ekonomik Düzeye Göre Annelerin Aile Yaşam Kalitesi Toplam Puan Ortalamalarına İlişkin Çift Yönlü Varyans Analizi Sonuçları

\begin{tabular}{|c|c|c|c|c|}
\hline Varyansın Kaynağı & df & Karelerin ort. & $\mathbf{F}$ & $\mathbf{p}$ \\
\hline \multicolumn{5}{|l|}{ Aile Yaşam Kalitesi } \\
\hline $\begin{array}{l}\text { Normal ya da Gelişimsel yetersizliğe } \\
\text { sahip çocuğu olma durumu }\end{array}$ & 1 & 519,30 & 10,58 &, $001^{* *}$ \\
\hline Sosyo-ekonomik Düzey & 1 & 6082,98 & 123,78 &, $000^{* *}$ \\
\hline $\begin{array}{l}\text { Normal ya da Gelişimsel yetersizliğe } \\
\text { sahip çocuğu olma durumu* Sosyo- } \\
\text { ekonomik Düzey }\end{array}$ & 1 & 157,34 & 3,20 & 075 \\
\hline
\end{tabular}

Normal gelişim gösteren ve gelişimsel yetersizliğe sahip olan çocuk babalarının sosyoekonomik düzeylerinin aile yaşam kalitesi toplam puan ortalamalarını istatistiki açıdan anlamlı olarak farklılaştırıp farklılaştırmadığını belirlemek amacıyla çift yönlü varyans analizi uygulanmıştır. Sonuçlar tablo 10'da görülmektedir. Yapılan analize göre sosyo-ekonomik düzey $(\mathrm{F}=124,57 ; \mathrm{p}=0,000<0.01)$ ve normal ile gelişimsel yetersizliğe sahip çocuğu olma durumu ( $\mathrm{F}=19,86 ; \mathrm{p}=0,000<0.01)$, kategorik değişkenlerinin aile yaşam kalitesi puanları ile arasında anlamlı farklılık bulunmuştur. Sosyo-ekonomik düzey ve normal ile gelişimsel yetersizliğe sahip çocuğu olma durumu ( $F=1,44 ; \mathrm{p}=0,231>0.05)$ değişkeninin, aile yaşam 
kalitesi puanları ile arasında ise anlamlı farklılık bulunamamıştır. Sosyoekonomik düzey ile ilgili ise orta ve üstü (Xort. $=100,96, s=0,63$ ) sosyoekonomik düzey algisına sahip olan babaların aile yaşam kalitesi algılarının alt ve orta-alt (Xort=90,85, s=0,65) sosyoekonomik düzey algısına sahip olan babalardan anlamlı derecede daha yüksek olduğu bulunmuştur.

Tablo 10. Sosyo-ekonomik Düzeye Göre Babaların Aile Yaşam Kalitesi Toplam Puan Ortalamalarına İlişkin Çift Yönlü Varyans Analizi Sonuçları

\begin{tabular}{lllll}
\hline Varyansın Kaynağı & df & Karelerin ort. & F & p \\
\hline Aile Yaşam Kalitesi & & & & \\
$\begin{array}{l}\text { Normal ya da Gelişimsel yetersizliğe } \\
\text { sahip çocuğu olma durumu }\end{array}$ & 1 & 843,10 & 19,86 &, $000^{* *}$ \\
$\begin{array}{l}\text { Sosyo-ekonomik Düzey } \\
\begin{array}{l}\text { Normal ya da Gelişimsel yetersizliğe } \\
\text { sahip çocuğu olma durumu* Sosyo- } \\
\text { ekonomik Düzey }\end{array}\end{array}$ & 1 & 5286,94 & 124,57 &, $000^{* *}$ \\
\hline
\end{tabular}

${ }^{*} p<.05,{ }^{* *} p<.01$

Normal gelişim gösteren ve gelişimsel yetersizliğe sahip olan çocuk annelerinin sahip oldukları çocuk sayısının aile yaşam kalitesi toplam puan ortalamalarını istatistiki açıdan anlamlı olarak farklılaştırıp farklılaştırmadığını belirlemek amacıyla çift yönlü varyans analizi uygulanmıştır. Sonuçlar tablo 11'de görülmektedir. Yapılan analize göre annelerin sahip oldukları çocuk sayısı $(\mathrm{F}=0,02 ; \mathrm{p}=0,891>0.05)$; sahip oldukları çocuk sayısı ve normal ile gelişimsel yetersizliğe sahip çocuğu olma durumu ( $F=0,74 ; \mathrm{p}=0,391>0.05)$, kategorik değişkenlerinin aile yaşam kalitesi puanları ile arasında anlamlı farklılık bulunmamıştır. Tek başına normal ile gelişimsel yetersizliğe sahip çocuğu olma durumu $(F=11,35 ; p=0,001<0.01)$ değişkeninin, aile yaşam kalitesi puanları ile arasında anlamlı farklılık bulunmuştur.

Tablo 11. Sahip Oldukları Çocuk Sayısı Göre Annelerin Aile Yaşam Kalitesi Toplam Puan Ortalamalarına İlişkin Çift Yönlü Varyans Analizi Sonuçları

\begin{tabular}{|c|c|c|c|c|}
\hline Varyansın Kaynağı & df & Karelerin ort. & $\mathbf{F}$ & $\mathbf{p}$ \\
\hline \multicolumn{5}{|l|}{ Aile Yaşam Kalitesi } \\
\hline $\begin{array}{l}\text { Normal ya da Gelişimsel yetersizliğe } \\
\text { sahip çocuğu olma durumu }\end{array}$ & 1 & 841,03 & 11,35 &, $001^{* *}$ \\
\hline Sahip Oldukları Çocuk Sayısı & 1 & 1,40 & 0,02 & 891 \\
\hline $\begin{array}{l}\text { Normal ya da Gelişimsel yetersizliğe } \\
\text { sahip çocuğu olma durumu* Sahip } \\
\text { Oldukları Çocuk Sayısı }\end{array}$ & 1 & 54,81 & 0,74 & ,391 \\
\hline
\end{tabular}

${ }^{*} p<.05,{ }^{* *} p<.01$

Normal gelişim gösteren ve gelişimsel yetersizliğe sahip olan çocuk babalarının sahip oldukları çocuk sayısının aile yaşam kalitesi toplam puan ortalamalarını istatistiki açıdan anlamlı olarak farklılaştııı farklılaştırmadığını belirlemek amacıyla çift yönlü varyans analizi uygulanmıştır. Sonuçlar tablo 12'de görülmektedir. Yapılan analize göre babaların sahip oldukları çocuk sayısı $(\mathrm{F}=0,05 ; \mathrm{p}=0,826>0.05)$; sahip oldukları çocuk sayısı ve normal ile 
gelişimsel yetersizliğe sahip çocuğu olma durumu ( $\mathrm{F}=0,15 ; \mathrm{p}=0,702>0.05)$, kategorik değişkenlerinin aile yaşam kalitesi puanları ile arasında anlamlı farklılık bulunmamıştır. Tek başına normal ile gelişimsel yetersizliğe sahip çocuğu olma durumu $(F=15,88 ; p=0,000<0.05)$ değişkeninin, aile yaşam kalitesi puanları ile arasında anlamlı farklılık bulunmuştur.

Tablo 12. Sahip Oldukları Çocuk Sayısı Göre Babaların Aile Yaşam Kalitesi Toplam Puan Ortalamalarına İlişkin Çift Yönlü Varyans Analizi Sonuçları

\begin{tabular}{lllll}
\hline Varyansın Kaynağı & df & Karelerin ort. & F & p \\
\hline Aile Yaşam Kalitesi & & & & \\
$\begin{array}{l}\text { Normal ya da Gelişimsel yetersizliğe } \\
\text { sahip çocuğu olma durumu }\end{array}$ & 1 & 1037,66 & 15,88 &, $000^{* *}$ \\
$\begin{array}{l}\text { Sahip Oldukları Çocuk Sayısı } \\
\text { Normal ya da Gelişimsel yetersizliğe }\end{array}$ & 1 & 3,17 & 0,05 &, 826 \\
sahip çocuğu olma durumu* Sahip & & 9,56 & 0,15 &, 702 \\
Oldukları Çocuk Sayısı & & & \\
\hline${ }^{*} p<.05,{ }^{* *} p<.01$ & & &
\end{tabular}

Normal gelişim gösteren ve gelişimsel yetersizliğe sahip olan çocuk annelerinin çalışma durumunun aile yaşam kalitesi toplam puan ortalamalarını istatistiki açıdan anlamlı olarak farklılaştırıp farklılaştırmadığını belirlemek amacıyla çift yönlü varyans analizi uygulanmıştır. Sonuçlar tablo 13 'de görülmektedir. Yapılan analize göre çalışma durumu ( $\mathrm{F}=1,05 ; \mathrm{p}=0,307>0.05)$; çalışma durumu ve normal ile gelişimsel yetersizliğe sahip çocuğu olma durumu ( $\mathrm{F}=2,19 ; \mathrm{p}=0,140>0.05)$, kategorik değişkenlerinin aile yaşam kalitesi puanları ile arasında anlamlı farklılık bulunmamıştır. Tek başına normal ile gelişimsel yetersizliğe sahip çocuğu olma durumu $(\mathrm{F}=7,19 ; \mathrm{p}=0,008<0.05)$ değişkeninin, aile yaşam kalitesi puanları ile arasında anlamlı farklılık bulunmuştur.

Tablo 13. Çalışma Durumuna Göre Annelerin Aile Yaşam Kalitesi Toplam Puan Ortalamalarına İlişkin Çift Yönlü Varyans Analizi Sonuçları

\begin{tabular}{|c|c|c|c|c|}
\hline Varyansın Kaynağı & df & Karelerin ort. & $\mathbf{F}$ & p \\
\hline \multicolumn{5}{|l|}{ Aile Yaşam Kalitesi } \\
\hline $\begin{array}{l}\text { Normal ya da Gelişimsel yetersizliğe } \\
\text { sahip çocuğu olma durumu }\end{array}$ & 1 & 530,17 & 7,19 &, $008^{* *}$ \\
\hline Çalışma Durumu & 1 & 77,16 & 1,05 & ,307 \\
\hline $\begin{array}{l}\text { Normal ya da Gelişimsel yetersizliğe } \\
\text { sahip çocuğu olma durumu* Çalışma } \\
\text { Durumu }\end{array}$ & 1 & 161,67 & 2,19 & ,140 \\
\hline
\end{tabular}

Normal gelişim gösteren ve gelişimsel yetersizliğe sahip olan çocuk annelerinin eşlerinden çocuğun bakımında destek alıp almadıklarının aile yaşam kalitesi toplam puan ortalamalarını istatistiki açıdan anlamlı olarak farklılaştırıp farklılaştırmadığını belirlemek amacıyla çift yönlü varyans analizi uygulanmıştır. Sonuçlar tablo 14' de görülmektedir. Yapılan analize göre annelerin aldıkları bakım desteği $(\mathrm{F}=1,74 ; \mathrm{p}=0,188>0.05)$; aldıkları bakım desteği ve normal ile gelişimsel yetersizliğe sahip çocuğu olma durumu ( $\mathrm{F}=0,44 ; \mathrm{p}=0,835>0.05)$, kategorik değişkenlerinin aile yaşam kalitesi puanları ile arasında anlamlı farklılık bulunmamıştır. Tek başına normal ile gelişimsel yetersizliğe sahip çocuğu olma durumu $(F=6,65 ; p=0,010<0.05)$ değişkeninin, aile yaşam kalitesi puanları ile arasında anlamlı farklılık bulunmuştur. 
Tablo 14. Aldıkları Bakım Desteğine Göre Annelerin Aile Yaşam Kalitesi Toplam Puan Ortalamalarına İlişkin Çift Yönlü Varyans Analizi Sonuçları

\begin{tabular}{|c|c|c|c|c|}
\hline Varyansın Kaynağı & df & Karelerin ort. & $\mathbf{F}$ & $\mathbf{p}$ \\
\hline \multicolumn{5}{|l|}{ Aile Yaşam Kalitesi } \\
\hline $\begin{array}{l}\text { Normal ya da Gelişimsel yetersizliğe } \\
\text { sahip çocuğu olma durumu }\end{array}$ & 1 & 490,88 & 6,65 &, $010^{*}$ \\
\hline Aldıkları Bakım Desteği & 1 & 128,65 & 1,74 & , 188 \\
\hline $\begin{array}{l}\text { Normal ya da Gelişimsel yetersizliğe } \\
\text { sahip çocuğu olma durumu* Aldıkları } \\
\text { Bakım Desteği }\end{array}$ & 1 & 3,22 & 0,44 & 835 \\
\hline
\end{tabular}

Normal gelişim gösteren ve gelişimsel yetersizliğe sahip olan çocuk annelerinin eşlerinden aldıkları bakımın türünün aile yaşam kalitesi toplam puan ortalamalarını istatistiki açıdan anlamlı olarak farklılaştırıp farklılaştırmadığını belirlemek amacıyla çift yönlü varyans analizi uygulanmıştır. Sonuçlar tablo $15^{\prime}$ de görülmektedir. Yapılan analize göre annelerin aldıkları bakım desteğin türü $(\mathrm{F}=0,58 ; \mathrm{p}=0,628>0.05)$; aldıkları bakım desteğin türü ve normal ile gelişimsel yetersizliğe sahip çocuğu olma durumu $(\mathrm{F}=0,54 ; \mathrm{p}=0,652>0.05)$, kategorik değişkenlerinin aile yaşam kalitesi puanları ile arasında anlamlı farklılık bulunmamıştır. Tek başına normal ile gelişimsel yetersizliğe sahip çocuğu olma durumu $(F=3,96 ; p=0,048<0.05)$ değişkeninin, aile yaşam kalitesi puanları ile arasında anlamlı farklılık bulunmuştur.

Tablo 15. Aldıkları Bakım Desteğinin Türüne Göre Annelerin Aile Yaşam Kalitesi Toplam Puan Ortalamalarına İlişkin Çift Yönlü Varyans Analizi Sonuçları

\begin{tabular}{|c|c|c|c|c|}
\hline Varyansın Kaynağı & df & Karelerin ort. & $\mathbf{F}$ & $\mathbf{P}$ \\
\hline \multicolumn{5}{|l|}{ Aile Yaşam Kalitesi } \\
\hline $\begin{array}{l}\text { Normal ya da Gelişimsel yetersizliğe } \\
\text { sahip çocuğu olma durumu }\end{array}$ & 1 & 293,12 & 3,96 &, $048^{*}$ \\
\hline Aldıkları Bakım Desteğinin Türü & 1 & 43,20 & 0,58 & 628 \\
\hline $\begin{array}{l}\text { Normal ya da Gelişimsel yetersizliğe } \\
\text { sahip çocuğu olma durumu* Aldıkları } \\
\text { Bakım Desteğinin Türü }\end{array}$ & 1 & 40,40 & 0,54 & 652 \\
\hline
\end{tabular}

\section{Tartışma}

Bu çalışmada, normal gelişim gösteren çocuklara sahip ebeveynler ile gelişimsel yetersizliğe sahip çocuğu olan ebeveynlerin aile yaşam kaliteleri incelenmiştir. Ayrıca normal gelişim gösteren çocukların ebeveynleri ile gelişimsel yetersizliğe sahip çocuğu olan ebeveynlerin arasında aile yaşam kalitesi değişkeni bağlamında karşılaştırma yapılmıştır. Bununla birlikte gelişimsel yetersizlik kategorisinde ele alınan zihinsel yetersizlik, otizm spektrum bozukluğu, Down sendromu, özgül öğrenme güçlüğü ve serebral palsi tanılı çocuğu olan anne-babaların da aile yaşam kalitesi algıları incelenmiştir. Çalışmanın bulguları gelişimsel yetersizliğe sahip çocuklu anne-babaların aile yaşam kalitesi algılarının normal gelişen çocuklu anne-babalardan daha düşük olduğunu göstermektedir. Özyurt (2011) yaptığ1 çalışmasında, zihinsel yetersizliğe sahip çocuğu olan annelerin aile yaşam kalitesi algılarının, normal gelişen çocuklu annelere göre anlamlı düzeyde düşük olduğu sonucuna ulaşmıştır. İki grubun anneleri arasındaki bu farklılığa sebep olan faktörler; annelerin yetersizliğe sahip çocuğun bakımıyla özel ilgilenmesi, kendilerine vakit ayıramaması, yetersizliğe sahip çocukla ilgili yaşanan 
finansal zorluklar gibi düşünülebilir. Aysan ve Özben (2007) tarafından yapılmış bir çalışma ise gelişimsel yetersizliğe sahip çocuğu olan babaların yaşam doyumlarının normal gelişim gösteren çocuğa sahip babaların yaşam doyumlarına göre daha düşük olduğu belirleyerek bu çalışmayı destekler niteliktedir.

Gelişimsel yetersizliğe sahip çocuğu olan anne-babalar ile normal gelişim gösteren çocuğa sahip anne-babalar aile yaşam kalitesi ölçeğinin alt boyutlarında karşılaştırılmıştır. Bu karşılaştırmanın sonucuna göre, gelişimsel yetersizlik gösteren çocukların anneleri ebeveynlik ve duygusal yeterlik alt boyutlarında normal gelişim gösteren çocuk annelerinden daha düşük, aile etkileşimi alt boyutunda ise daha yüksek puanlar almışlardır. Şirin (2014) tarafından yapılan bir çalışmada bu çalışmanın bulgularıyla benzer şekilde normal gelişim gösteren çocuğa sahip ailelerin aile yaşam kalitesi alt boyut algıları gelişimsel yetersizlik gösteren çocukların ailelerine kıyasla anlamlı derecede yüksek bulunmuştur. Meral (2011) ise, gelişimsel yetersizliği olan çocuk annelerinin aile yaşam kalitesi ve alt alan algılarından en yüksek algısının "aile etkileşimi"e alt alanında, en düşük algının ise "fiziksel/materyal/finansal yeterlik"e alt alanında olduğunu ifade etmiştir. Gelişimsel yetersizliğe sahip çocuğu olan ailelerin aile yaşam kalitesi alt alanları içerisinde en yüksek algılarının "aile etkileşimi" alt boyutunda olduğunu destekleyen pek çok çalışma bulunmaktadır (Balcells-Balcells ve ark., 2010; Brown, Petrowski, Edwards, Isaacs, Brown, Baum ve ark., 2010; Clark, Brown ve Karrapaya, 2011; Cagran, Schmidt ve Brown, 2011). Tüm bu çalışmaların bulgularına paralel olarak aile etkileşimi alt boyutunda gelişimsel yetersizliğe sahip çocuğu olan annelerin daha yüksek puan alması, ailenin çocuğun yetersizliğini öğrendiği an ve sonrasında bir olarak yetersizlikle mücadele etmesi, dayanışma içinde olarak zorlukların üstünden gelmeye çalışılmasının aile içi etkileşim güçlendirdiği şeklinde açıklanabilmektedir (Bayat, 2005; Patterson, Holm ve Gurney, 2004). Gelişimsel yetersizlik gösteren çocukların babalarının ise yalnızca ebeveynlik alt boyutlarında normal gelişim gösteren çocuk babalarından daha düşük puanlar aldıkları görülmüştür. Aile etkileşimi alt boyutunda ise anneler ile benzerlik göstererek daha yüksek puanlar almışlardır.

Farklı tanı grupları ele alındığında, otizm ve Down sendromlu çocuklu anne-babaların yaşam kalitesi algıları normal gelişen çocuklu anne-babalara göre anlamlı derecede düşük bulunmuştur. Zihinsel yetersizliğe sahip çocuklu babaların yaşam kalitesi algılarının normal gelişen çocuklu babalara kıyasla anlamlı derecede düşük olduğu bulunmuşken, annelerde bir farka rastlanmamıştır. Diğer tanı grupları ile ise anlamlı bir farklılık bulunamamıştır. Literatür incelendiğinde, Brown (2006) yaptığ1 çalışmada normal gelişim gösteren çocuğun ailelerinin diğer iki gruba kıyasla aile yaşam kalitesi algılarının daha yüksek olduğu tespit etmiştir.

Çalışmanın bir diğer sorusunda, gelişimsel yetersizliğe sahip çocuğu olan anne-babaların ve normal gelişim gösteren çocuğa sahip anne-babaların aile yaşam kalitesi ölçeği toplam puanlarında demografik değişkenler (sosyoekonomik düzey, eğitim düzeyi, eşten alınan destek, alınan desteğin türü, çocuk sayısı, çalışma durumu) açısından anlamlı olarak farklılaşma olup olmadığına bakılmıştır ve eğitim düzeyi ortaokul ve altı olan gelişimsel yetersizlik gösteren çocukların annelerinin aile yaşam kalitesi puanları eğitim düzeyi lise ve üstü normal gelişim gösteren çocukların annelerinin puanlarından daha düşük bulunmuştur. Ahmet (2017) tarafından yapılan Batı Trakya' da engelli çocuğa sahip azınlık ailelerinin yaşam kalitesinin incelendiği bir çalışmada, benzer şekilde eğitim düzeyi yalnızca okuryazarlık olan anne-babaların yaşam kalitesi ortaokul, lise ve üniversite olan ebeveynlere göre daha düşük bulunmuştur. 
Çalışmanın sosyoekonomik düzey ile ilgili bulgularına bakıldığında, gelişimsel yetersizliğe sahip çocuğu olan anne-baba ile normal gelişim gösteren çocuğa sahip anne-baba olma durumu ve anne-babaların sosyoekonomik düzeyi birlikte ele alındığında, bu değişkenlerin birlikte aile yaşam kalitesi puanları üzerine etkisi olmadığı gözükmektedir. Sosyo-ekonomik düzey değişkeninin tek başına aile yaşam kalitesi puanları ile arasında anlamlı farklılık bulunmuştur. Eğitim düzeyi ve sosyoekonomik düzey dışında kalan diğer demografik değişkenlerin ise anlamlı bir etkisi bulunamamıştır.

Bu çalışmada normal gelişim gösteren çocuklara sahip ebeveynler ile gelişimsel yetersizliğe sahip çocuğu olan ebeveynlerin aile yaşam kaliteleri incelenmiştir. Yapılan çalışmalara bakıldığında, verilerin daha çok annelerden elde edildiği görülmektedir. Bu sebeple bu çalışmada olduğu gibi babaların aile yaşam kalitesi ve alt boyut algılarını belirlemek adına babalardan da veri toplanarak çok daha fazla çalışma yapılabilir. Aynı şekilde Literatür incelendiğinde annelerin eşlerinden aldıkları desteğin ele alındığı bir çalışmaya rastlanmamıştır. Yapılan çalışmalarda genellikle sosyal destek algılarının incelendiği görülmektedir. Bu sebeple başka çalışmalarda bu değişkenin tekrar ele alınmasının, bu çalışmayı destekleyen ya da reddeden bir sonuç ile literatüre katkı sağlayabileceği düşünülmektedir.

Sosyo-ekonomik düzey değişkeninin aile yaşam kalitesi puanları üzerinde bir etkisi olduğu bulgusuna bu çalışmada ulaşılmıştır. Bu bağlamda düşük sosyo-ekonomik düzeye sahip aileler için özellikle sağlık alanında yeterli hizmeti alabilmek adına önleyici yöntemler üzerinde durulmasının yaşam kalitelerini artırmada büyük rol oynayabileceği düşünülmektedir. Aynı şekilde gelişimsel yetersizliğe sahip çocuğu olan anne-baba ve kardeşlere psikolojik ve sosyal desteğin arttırılmasının önemli olduğu düşünülmektedir. Benzer sorunlardan dolayı zorluklar yaşayan ailelerin bir araya geldiklerinde birbirlerini empatiyle daha iyi anlayacağı düşünülerek, günümüzde çok fazla örneği bulunan "kendine yardım grupları" gibi bir topluluk oluşturmalarının da anne-babaların karşılaştıkları güçlüklerle başa çıkmasını kolaylaştırabileceği düşünülmektedir.

\section{KAYNAKÇA}

Ahmet, S. (2017). Batı Trakya'da engelli çocuğa sahip azınlık ailelerinin yaşam kalitesinin incelenmesi. Trakya Üniversitesi Sosyal Bilimler Dergisi. 19(1), 461-474

Ahmetoğlu, E. (2004). Zihinsel engelli çocukların kardeş ilişkilerinin anne ve kardeş algılarına göre değerlendirilmesi. (Yayınlanmamış Doktora Tezi). Ankara Üniversitesi Fen Bilimleri Enstitüsü.

Aldersey, M. H. (2012). Family perceptions of intellectual disability: Understanding and support in Dar es Salaam. African Journal of Disability, 2012, 1(1): 32.

Aysan, F. ve Özben Ş. (2007). Engelli çocuğu olan anne-babaların yaşam kalitelerine ilişkin değişkenlerin incelenmesi, Dokuz Eylül Üniversitesi Buca Eğitim Fakültesi Dergisi, 22: 1-6.

Balcells-Balcells, A., Giné, C., Guàrdia-Olmos, J., \& Summers, J. A. (2010). Family quality of life: adaptation to Spanish population of several family support questionnaires. Journal of Intellectual Disability Research, 55(12), 1151-1163. doi:10.1111/j.1365-2788.2010.01350.x

Bayat, M. (2005). How family members' perceptions of influences and causes of autism may predict assessment of their family quality of life. (Unpublished Doctoral Dissertation). Loyola Univesity, Chicago. 
Beach Center on Disability at the University of Kansas, in partnership with families, service providers and researchers (2006). Family Quality of Life Survey. Beach Center: University of Kansas.

Brown, I., Petrowski, N., Edwards, M., Isaacs, B.J., Brown, R.I., Baum, N., \& Werner, S. (2010). A family quality of life approach for social workers: lessons from the field of intellectual and developmental disabilities. Journal of Family Social Work, 1-25.

Brown, R. I. (2006). Editorial. Journal of Policy and Practice in Intellectual Disabilities, 3(4), 209210.

Cagran, B., Schmidt, M., \& Brown, I. (2011). Assessment of the quality of life in families with children who have intellectual and developmental disabilities in Slovenia. Journal of Intellectual Disability Research, doi: 10.1111/j.1365- 2788.2011.01400.x, 1-12.

Canarslan, H. ve Ahmetoğlu, E. (2015). Engelli çocuğa sahip ailelerin yaşam kalitesinin incelenmesi. Trakya Üniversitesi Sosyal Bilimler Dergisi, Cilt: 17, Sayı: 1 (13-31).

Clark, M., Brown, R., \& Karrapaya, R. (2011). An initial look at the quality of life of Malaysian families that include children with disabilities. Journal of Intellectual Disability Research, doi: 10.1111/j.1365-2788.2011.01408.x. 1-16.

Deveci-Şirin, S. (2014). Ailelerde sosyo-demografik-ekonomik değişkenlerin aile yaşam kalitesine etkileri. Anadolu Ĕ̆gitim Liderliği ve Öğretim Dergisi, 2 (1), 31-46.

Görgü, E. (2005). 3-7 yaş arası otistik çocuğa sahip olan annelerin algıladıkları sosyal destek düzeyleri ile depresyon düzeyleri arasındaki ilişki (Yayımlanmamış Yüksek Lisans Tezi). Marmara Üniversitesi Eğitim Bilimleri Enstitüsü, İstanbul.

Hoffman, L., \& Marquis, J. (2006). Assesing family outcomes psychometric evaluation ofbeach center family quality of life scale. Journal of Marriage and Family, 68, 1069-1083.

Küçüker, S., Ceber-Bakkaloğu, H. ve Sucuoğlu, B. (2001). Erken eğitim programina katılan gelişimsel geriliği olan çocuklar ve anne-babalarının etkileşim davranışlarındaki değişimin incelenmesi, Ankara Üniversitesi, Eğitim Bilimleri Enstitüsü Özel Eğitim Dergisi, 3(1): 61-71.

Meral, B. F. (2011). Gelişimsel yetersizliği olan çocuk annelerinin aile yaşam kalitesi algılarının incelenmesi. (Yayınlanmamış Doktora Tezi). Anadolu Üniversitesi Eğitim Bilimleri Enstitüsü.

Milgram, N. A., \& Atzil, M. (1988). Parenting stres in raising autistic children. Journal of Autism and Developmental Disabilities, 18, 415-424.

Özmete, E. (2010). Aile yaşam kalitesi dinamikleri: Aile iletişimi, ebeveyn sorumlulukları, duygusal, duygusal refah, fiziksel materyal refahın algılanması. Uluslararası Sosyal Araştırmalar Dergisi, 3(11), 455-465.

Özyurt, Ö. (2011). Hafif zihinsel engelli çocuğu olan annelerin algıladıkları aile işleyişi ve aile yaşam kalitesinin sosyo-demografik değişkenler açısından incelenmesi, (Yüksek Lisans Tezi). T.C Maltepe Üniversitesi, Sosyal Bilimler Enstitüsü: İstanbul.

Patterson, J.M., Holm, K.E., \& Gurney, J.G. (2004). The impact of childhood cancer on the family: A qualitative analysis of strains, resources, and coping behaviors. PsychoOncology, 13(6), 390-407. 
Poston, D., Turnbull, A., Park, J., Mannan, H., Marquis, J., \& Wang, M. (2003). Family quality of life: A qualitative inquiry. Mental Retardation, 41(5), 313-328.

Seed, P., \& Lloyd, G. (1997). Quality of Life. London: Jessica Kingsley Publishers Ltd

Semerci, Z.B. ve Turgay, A. (2011). Bebeklikten erişkinliğe dikkat eksikliği - hiperaktivite bozukluğu. (5. Basım). İstanbul: Alfa Basım Yayım Dağıtım.

Turnbull, H.R., Turnbull, A.P., Wehmeyer, M.L., \& Park, J. (2003). A quality of life framework for special education outcomes. Remedial and Special Education, 24, 67-74.

World Health Organization QoL Group (1999). The World Health Organization Quality of Life Assessment (WHOQOL). Position Paper form the World Health Organization - Social Science and Medicine, 41: 1403-1409.

Yıldız, D. (2009). Okul öncesi dönem engelli çocuğa sahip annelerin çocuklarını kabullenişleri ile umutsuzluk düzeylerinin karşılaştırılması (Yayımlanmamış Yüksek Lisans Tezi). Marmara Üniversitesi Eğitim Bilimleri Enstitüsü, İstanbul. 